\title{
Female Depression Through Symbolism: A Study on the Selected Poems of Adrienne Rich
}

\author{
Md. Jahidul Azad \\ $\mathrm{PhD}$ (Fellow), Assistant Professor \\ Department of English \\ Prime University, Bangladesh \\ Mirpur, Dhaka, Bangladesh \\ amir.hossain.16578@gmail.com
}

Abstract

This paper talks about Adrienne Rich's support and standing with the women through her selected poems. The paper discusses the depression of women because of male dominance. Rich uses symbolism to display women depression. She also tries to clear the position of woman in the society. The research demonstrates the position of women through psychoanalysis, social problems and female point of view. This paper also tries to identify Rich's view on feminism. Adrienne Rich has highlighted the hard reality in her writings. This paper also clarifies Adrienne Rich's thinking or point view regarding feminism and sexuality. Her experiences regarding the depression of women are displayed here through symbolism. Thus the focal point of the paper is to show how Adrienne Rich shows female depression through symbolism.

Keywords: Symbolism, Women Depression, Hope, Psychology, Feminism. 
Introduction

Adrienne Rich (1929-2012) was brought up in a milieu that was totally fashioned by patriarchal thought in every field of life. Great male figures mastered the literary scene and they created their rules for what should be written and what should not. Rich's legibility to write poetry was only found in the imitation of poetic conventions of the canon. She started writing poetry that matches the literary styles and subject matters of the period; a period that was totally fashioned by male writers' thought. Moreover, Rich was raised in a family who fed her mind with the importance of reading and imitating the great figures of literary scene (Hassan 55). A Change of World (1951) was her first collection of poems that were complemented by W. H. Auden himself in his preface to this collection. Auden said: In a young poet, as T. S. Eliot has observed, the most promising sign is craftsmanship for it is evidence of a capacity for detachment from the self and its emotions without which no art is possible. Craftsmanship includes, of course, not only a talent for versification but also an ear and an intuitive grasp of much subtler and more difficult matters like proportion, consistency of diction and tone, and the matching of these with the subject at hand; Miss Rich's poems rarely fail on any of these counts" (Rich 278). "It is noted above that craftsmanship, decorum and detachment were really what matter for those writers. The poetic conventions at that time entailed the writing about public issues that matter public opinions. More importantly, woman writer had nothing but to follow the rules of writing sponsored by the great masculine writers of the period. Thus, she had to talk about impersonal issues, which led to the burial of her female voice in her writings. That was the milieu that characterized the early poetry of Adrienne Rich to the extent that she was given the label of 'great imitator'. Following these formalistic techniques and modes of expression left Rich incapable of finding the appropriate means to voice herself in her writings. She couldn't talk about her ambitions and concerns as a woman having a life ruled by masculine thinking. Thus, she lived a duality of life between 
satisfying the demands of great male pioneers of the period and the following of her needs and desires as a woman seeking her own female identity" (Hassan 56). Moreover, Rich realized that the distinction of man at the expense of woman did not lie in certain innate attributes or characteristics, but it was imposed on woman by force. She wrote in her essay, When We Dead Awaken: Writing as Re-Vision (1971) that "The charisma of Man seems to come purely from his power over her and his control of the world by force, not from anything fertile or life-giving in him" (36). Though Rich's realizations of the oppressive doctrine of writing poems separate from the poet's everyday life, she could not save herself and reflect her voice in her early poems because she was still using the same tools and modes of writing of the common male writers. These modes of writing convey only the fixed meanings of what Lacan called 'the symbolic language' that serves the masculine needs and neglects the feminine ones. Women are dominated in our society but there is none to end this problem. Rich feels the depression the depression of the women as she is also a woman. She decides to display it through her poetry and she tries. We know if the child wants to get an access into his own subjectivity. The child should give up his first identification and attachment with his mother in order to construct an identity that copes with the patriarchal model, which in turn favors the masculine over the feminine. So the society doesn't recognize a child by its mother's identity. Woman has no right on her children. The patriarchal society is not ready to recognize any woman which is the main cause woman's depression. Adrienne Rich was against this in justice and she protests against it through symbolism in her writings. So Rich's writings reflect women's psychological aspect (depression) and the use of symbolism.

Adrienne Rich's poetry displays the condition woman in the second half of the twentieth century. Many researchers attempt to trace out all the elements which are used the writings of Adrienne Rich. They also try to decode the hidden messages of her writings. So the researchers conducted many researches in this field. The researcher is also active till now 
regarding this. They find out many things. Aparsh P. shows the picture of gender discrimination in the poetry of Adrienne Rich. He conducted a research name: "Gender Discrimination in selected poems of Adrienne Rich". Lena Petrovic is another researcher who works in the same field. His research paper is "Gender and Difference in the Poetry of Adrienne Rich". P Jayasadhu researches on the feministic aspect of Adrienne Rich's poetry. His research titles "A Feministic Perspective of Adrienne Rich". It is known to us that some of the poems of Rich like; the collections Necessities of Life (1966), Leaflets (1969), and The Will to Change (1971) openly reject patriarchal culture and language. Women are depended on the males. Adrienne Rich wanted the establishment of women identity. Researchers also work on this aspect. Mahsa Maheshi has his paper on it named; "Woman defined Identity: Analysis of Selected poems of Adrienne Rich". A woman faces a lot of hatred because of being a female. The researchers also notice it and there a research paper of Francisco Jose Cortes Vieco. The name of the research paper is "I hate Woman. They got on My Nerves: Drothy Parker's Poetry of Female Sympathy". Adrienne Rich was very influenced by the Symbolist Movement and we get many symbolist elements in her poetry. She frequently uses symbolism in her poetry. "A Symbolic Reading of Adrienne Rich's An Unsaid Word" is an example of a research paper which works on the symbolic representation in Adrienne Rich's poetry. Mohamad Fleih Hassan, Hardev Kaur and Manimangai Mani are the researchers of this research. There are many other researches which are available on Adrienne Rich like: “The Unslept Unsleeping Elsewhere: Radical Contemporary in the last poems of Adrienne Rich" by Prokash Kona. Adrienne Rich's poems are not only about the aspects those are stated above in the discussion but also there are many other aspects. One thing which is missed by the scholar is women's depression. There are many poems of Adrienne Rich which display women depressions. The poems are; Aunt Jennifer's Tigers, Snapshots of a Daughter-In-Law, My Mouth Hovers Across Your Breasts, Living In Sin, 
I Dream I'm the Death of Orpheusetc. The representations of women's depression are here through symbolism. Here researches are conducted on symbolism but there is no attempt of research based on woman depression through symbolism regarding Adrienne Rich. So it is a prominent research problem which is unsolved. It must be solved to enrich the field of study. It is also important to fulfill the research gap. So it is attempted to fulfill the literature gap and solve the literary problem.

"The symbolic Language is the means of circulating man's power because language provides the symbol connectors by which the world is interpreted" (Hassan 58). The poststructuralists think that the "process of symbolic activity does more than construct the ideal model of domination. It actively plays a part in the construction of thought as it attempts to structure experience" (Kirsch 42). The use of symbolism in the poems of Adrienne Rich is very common. It is one of the most notable characteristics of her writings. Aunt Jennifer's Tiger is one of her poems. The messages of the poem are symbolic. It is a poem about an oppressed woman who escapes into an alternative world of embroidery and sewing, despite a heavy marriage to a terrifying man. It's a formal rhyming poem, an early example of Adrienne Rich's work. The speaker provides much information about Aunt Jennifer by using symbols. Many deep and hidden words are there, which are trying to some other words. The tiger of this poem is not a real tiger.

When Aunt is dead, her terrified hands will lie

Still ringed with ordeals she was mastered by.

The tigers in the panel that she made

Will go on prancing, proud and unafraid. (Rich, 1951: 13-16)

Through these symbolic lines Rich wants to say that the oppression of woman will end after their death but it will be recognized by anyone. Everyone will forget the miseries of the woman and other woman will be dominated and oppressed by the society. Thinking about 
this reality, the speaker becomes frustrated. The Tiger is also a symbol of frustration, depression and the pain of the oppressed woman. There is another poem of Rich in which she uses symbolism in order to display the depression of women. The name of the poem is My Mouth Hovers Across Your Breast. It displays the hope, dominance and depression. Women want a happy family life and try to live in happiness with their family. Every woman leaves their parents and siblings to live with her husband. She dedicates her life for her husband and children. She looks after them and cares them but in most of the time she doesn't get any feedback. Most of the husbands of our society treat their wives as their property. They impose rules like a dictator and don't care about their wives. Women sacrifice many things but they get nothing in return. Their love and affection is overlooked by the family. The expectations of family from women are never ending. Women cannot expect anything from the male dominant family and society. They are not allowed to ask for their rights. When women try to raise their voices, society stops them. It obviously makes the women frustrated. They manage to overcome it. They don't lose hope as they love the family and society. They believe today or tomorrow, they will be treated properly and they will enjoy their rights.

Adrienne Rich herself also says about her depression. Some lines from one of her interview: "I find the condition of life in this country often very depressive. The work that I choose to do is very much in part to not get lost and paralyzed. The activism I choose to do, the kind of writing I choose to do has a lot to do with that, with going to the point where I feel there is some energy. And there is a lot of energy in this country, but it's diffused, it's scattered, it's localized." (Rich 35). Adrienne Rich is always hopeful, and she knows that her path is full of obstacles but she is unchanged. As a woman, he faces depression but she wants the country changed. So she is writing against it. She doesn't want to stop. She will move forward. Her thoughts are like the Himalayans. Probably, she is quite successful regarding 
this matter as her poems are full with feministic elements. Most of her poems centers on women. Her poems are like the representation of women's psychological status.

She had thought the studio would keep itself;

no dust upon the furniture of love.

Half heresy, to wish the taps less vocal,

the panes relieved of grime. A plate of pears,

a piano with a Persian shawl, a cat

stalking the picturesque amusing mouse

had risen at his urging. (Rich: 1950, 1-7)

The title of this poem is Living in Sin. It is a psychoanalysis of women, which expresses the psychological condition of the woman in the poem. "The woman in this poem fantasized and expected a perfect relationship by daydreaming and hoping that her relationship will never have difficulty and hardship. However, down the line her imagination backfired, and the reality took over" (Gradesfixer 2019). Women don't experience their expected life. Their dream remains dream. The mouse in the poem symbolizes their depression, and it is originated from the family and society. The cat actually symbolizes the rude behavior of the family and society towards women. "The poem, Living in Sin, lets us know that we're dealing with an unmarried couple living together. The poem describes a big difference between the way the woman imagined her studio would look — absolutely perfect and charming — and the way it actually looks: really run down and in need of a serious cleaning! Meanwhile, the man in the relationship acts bored and goes off on a boring errand. Later that night, the woman feels a bit better, but she's kept awake by the thought of what tomorrow will bring" (Shmoop 2008).

Adrienne Rich writes about the women and supports them through her poem. She tries to establish herself as feminist till 1970. Now she does not consider herself as feminist. She says 
about this in an interview; "I think it was then that I first used the world about myself. It's odd because there's so much discussion now about whether young women want to be labeled as feminist or not. And I remember thinking I didn't want to be labeled as feminist. Feminist were these funny creatures like Susan B. Anthony, you know. She was a laughingstock when I was growing up. Or Carrie Nation. They were caricatured." (Rothschild 32-33) Whatever she says her poems are feminist.

"Snapshots of a Daughter-in-law by Adrienne Rich is a pungent feminist poem in which Rich explores multiple facets of a woman's life, inflicted with sorrows and male exploitation. The title itself hints at discontinued, disorderly photographs of a woman, daughter-in-law, the relation dominantly linked with son. Rich has deliberately selected daughter-in-law not sister or daughter in order to disclose a position of a woman who has hardly lived as an independent daughter but a dependent daughter-in-law. It is mainly about anxiety of a modern woman. The poem creeps from experiences of a woman at her house working continuously throughout the days, serving her husband with her body at night, continuing a routine, monotonous life by sacrificing her wishes, ambitions and cheers - then it moves towards a revolutionary tone and encourages woman to be bold and to demand her rights, declare independence from family fetters. Towards the end, the poem explodes into a devastating weapon for the might and right of woman” (Bachelor and Master 2013).

A thinking woman sleeps with monsters.

The beak that grips her, she becomes. (Rich, 1970: 2639)

Women are deprived by the men. Their husbands are the persons who dominate them most. So the depression of the women symbolizes the men as monsters. It is usually very tough for any woman or man to sleep with the person who dominates her or him most. Women have to do it for the whole life so their depression knows no limit. 
We are familiar with a term lesbian. A lesbian is a homosexual woman. Adrianne Rich also writes for them. Compulsory Heterosexuality and Lesbian Existence is an essay of her regarding this."It was written to challenge the erasure of lesbian existence from a large amount of scholarly feminist literature. It was not written to widen divisions but to encourage heterosexual feminists to examine heterosexuality as a political institution which disempowers women and to change it" (Kafer 2003). It is a gift for the all depressed lesbians who fell insecure to express their feelings and demands. It is an attempt to change the notion of women's dependence on men as social and economic supports, as well as for adult sexuality and psychological completion.

\section{Conclusions}

Adrienne Rich's writings on the oppression of woman are a very brave attempt as we are living in the male dominant society. She tries best to cover up her protest by using symbolism. She also uses symbolism to show female depression. The paper will help us to identify the use of symbolism in Adrienne Rich's writings to show female depression. People will get a clear view about Female Depression in Rich's writings. They would be more careful about their female family members and would respect them and provide their rights. It will build a better family and society. Finally, all will be equal. 


\section{Works Cited}

Fixer, Grades. “Analysis of Adrienne Rich’s Poem “Living in Sin.” 2019.

Hassan, Mohamad, Fleih, Rosli bin Talif, and Hardev Kaur. "Resurfacing Female Identity via Language in Adrienne Rich's Diving into the Wreck". Mediterranean Journal of Social Sciences, 2015, p.245.

Hassan, Mohamad, Fleih, Hardev Kaur and Manimangai Mani. "A Symbolic Reading of Adrienne Rich's An Unsaid Word”. International Letters of Social and Humanistic Sciences, 2016, pp.55-60.

Kafer, Alison. "Compulsory Bodies: Reflections on Heterosexuality and Able-bodiedness". Journal of Women's History, 15 (3), 2003, pp.77-89.

Kirsch, Max, H. Queer Theory and Social Change. New York: Psychology Press, 2000.

Rich, Adrienne, Gelpi, Barbara Charlesworth. Adrienne Rich's Poetry and Prose. New York: Norton, 1993.

Rich, Adrienne. A Change of World. New Heaven: Yale University Press, 1951.

Rich, Adrienne. “The New Yorker Magazine”. January 23, 1954.

Rich, Adrienne. Snapshots of a daughter-in-law. London. 1970.

Rothschild, Matthew. "Adrienne Rich: I happen to think poetry makes a huge difference." The Progress January, 1994, pp.31-34.

Shmoop Editorial Team. "Living in Sin Summary.” Shmoop. Shmoop University, Inc., 2008. 